\title{
Relationship Between Operational Frameworks and Performance of Community Based Organizations in Implementing Agricultural Extension Services in Buuri Sub-County, Meru County, Kenya.
}

\author{
${ }^{1}$ Njagi Michael Hezekiel Waweru, ${ }^{2}$ Dr. John Wanjohi \\ ${ }^{1}$ Researcher, University of Nairobi, Meru Extra Mural Centre, Meru, Kenya \\ ${ }^{2}$ Senior Lecturer, Department of Chemistry, University Of Nairobi
}

*Corresponding Author: Njagi Michael Hezekiel Waweru, Researcher, University of Nairobi, Meru Extra Mural Centre, Meru, Kenya

\begin{abstract}
Agriculture remains the main source of income for many people in the world especially the rural populace. Yet the continued existence of substandard agricultural extension services provided by government has many rural farmers realizing poor crop yields and meager disposal incomes. The emergence of community based organizations (CBOs) providing agricultural extension services, is thought to cure these societal concern. This study investigated the relationship between operational frameworks and performance of community based organizations implementing agricultural extension services in Buuri Sub County in Meru County. The study is pivoted on one theory; Core Competencies Theory. Descriptive survey research design guided the study. Target population consisted of 1,870 respondents of whom 62 were community based organizations' officials and 1,808 members. The study's sample size was made up of 319 respondents and Stratified sampling was employed to classify CBOs in 3 strata based on their main value chains and final subjects selected using Simple random sampling technique. Primary data was collected through the use of questionnaires for registered CBOs' members and an interview guide for CBOs' officials. Quantitative data was analyzed making use of descriptive statistics while qualitative data was outlined in descriptions guided by themes under investigation. The study established that the use of information communication technologies (ICT), working monitoring and evaluation systems, recruitment of qualified staff and a clear organizational structure all exhibited a relationship with the performance of CBOs providing agricultural extension services. The study concluded that operational frameworks had a pivotal role in performance of CBOs providing agricultural extension services as they promoted a corporate culture and integrated principles of good governance in the organizations. The study recommends that to attain set out goals and excellent performance, CBOs in the study locale must have strong operational frameworks in place.
\end{abstract}

Key Terms: Agricultural Extension Services, Community Based Organizations, Operational Frameworks, Monitoring and Evaluation Systems, Information Communication Technologies

\section{BACKGROUND TO THE STUDY}

Agricultural extension has long been seen as a key element for enabling farmers to obtain information and technologies that can improve their livelihoods (Purcell and Anderson, 1997) and is recognised as an important factor in promoting agricultural development (Birkhaeuser et al., 1991; Anderson and Feder, 2007).Yet negative experiences with extension in the past have sparked considerable debate worldwide about the best way to provide and finance agricultural extension. However, according to Anderson and Feder, (2004) it is generally accepted that only a well-performing extension service can make significant contributions to improved agricultural growth and the welfare of poor people. It is in this regard that Nambiro, et al., (2006) and Rees, et al., (2000) posits that it was as a result of ineptness in the public extension system, a third type of extension service; private agricultural extension system has emerged comprising of private companies, nongovernmental organizations (NGOs), community-based organizations (CBOs), and faith-based organizations. Community based organizations serve as the apex organizations by which communities can embark on agricultural development projects, small scale industries, vocational and trade, skills, rural transportation and other rural economic activities (Fakoya et al., 2000; Awa and Ema, 1992; Adejumobi, 1997). 
Several developed countries have fully or partially privatized their agricultural extension services in a variety of ways. Terms like outsourcing, cost-recovery, and contracting out are related to the drive for privatization (Farrington, et al., 2002). These reforms resulted into enhanced food security. Costa Rica has a unique system under which the government provides farmers with extension vouchers which can be used for getting extension advice from private specialists. The trend has resulted into demand driven extension services.

In the UK, a private extension sector has been active for many years, even before the public Agricultural Development Advisory Service (ADAS) was privatized (Garforth,2002).The Indian government has launched an ambitious initiative to encourage private extension with the Ministry of Agriculture and the National Bank (NABARD). Graduates are being trained to become 'agripreneurs' and on completion of their courses they receive a loan to establish an 'agriclinic' or 'agribusiness centre'. Farmers are expected to pay a fee for their services and the agripreneurs are expected to identify the demand for a broad range of services from soil testing to advice on organic production and food processing. So far 112 businesses have been set up in 10 states and it is intended that the new services will provide specialist advice that may be beyond the scope of the service presently offered to farmers through public extension (Shekara and Charyulu, 2002).

The United States Extension System (SES) was criticized for lack of relevance (Dillman, 1986). As a result, the SES was reviewed and a new set of issues-oriented initiatives designed to revitalize the relevance of the system (Gustafson, 1991). Other systems have embraced partial privatization. The Netherlands, for instance, decided to privatize half of its public extension agents, while the other half were assigned various responsibilities such as linking research and privatized extension services (Le Goius, 1991).

When asked to go commercial in 1986 (Hercus, 1991), New Zealand Ministry of Agriculture and Fisheries started operating under a potentially controversial user-pay, commercial system. Other public extension approaches moved towards cost-recovery approaches. Mexico, for instance planned for a fee based system for both large scale and the small scale farmers (Wilson, 1991). In Albania, the private sector entrepreneurial initiatives to create a long-term relationship with farmers have proved to be successful (World Bank/USAID. 2002). Estonia has both a public extension advisory service for poor farmers and a private service for better-off farmers (FAO, 2003).

In Israel, the efforts to even semi-privatize national extension services have not always been met with success. The government is still responsible for providing extension advice, but encourages privatization through the standing practice of growers to contribute portion of their income to research and development including extension, public and private partnership in financing and operating units within the extension service, payment for services by commodity production and marketing boards beyond a basic extension package, the provision of more intensive extension activities at the request of needy growers, special agreements with commodity farmers' organizations, extension staff working on their day off in exchange for direct payment from farmers, provision of equipment like mobile phones to extension advisers by growers associations, and direct payment by farmers for participation in training activities (Rivera, 2013).

Nigeria probably has the most elaborate research and extension institution in Sub-Saharan Africa (Okwu and Ejembi, 2001). In Nigeria, agricultural extension service has been mainly public. Currently the major provider of public sector agricultural extension services is the agricultural development programmes (ADPs) in each of the 36 states of Nigeria. The pre-ADP Extension Services (The conventional extension system) were presumed to be ineffective and could only provide limited services to the majority of farmers in the basic farming enterprises due to bureaucratic bottlenecks. This formed the basic fact underlying the removal of the extension service from the civil service system and the introduction of ADP in the early 70s.It has now become the only functional public extension service provider in the country (Ekpere, 1991).

Uganda is experimenting with the privatization of extension through the creation of a pool of private extension specialists out of its existing public extension service; registered farmers' associations could call upon this pool through bidding for providing services related to selected enterprises, and pay for the services from the funds given to them by the donors through decentralized government units. It is 
indeed a bold experiment, but the sustainability of this arrangement remains to be seen after the donors' funding runs out (Mubangizi, et al., 2014). Ugandan government put in place policies that promote decentralization, privatization, and liberalization and developed a new plan for modernization of agriculture in the late 90s, (Oryokot, 2003).

Kibett, et al., (2012) posits agricultural extension policy in Kenya has suffered the following setbacks; aging and reduced staffing and funding for operations, lack of participatory technology development, and poor packaging and information dissemination. The policy lacks the capacity to control conflicting messages to the farmers, such as unnecessary competition, duplication of efforts, and general lack of synergy among these extension providers in Kenya. Nonetheless, in recognition to all this, the Kenya Government is currently implementing the National Agricultural Extension Policy (NAEP) which was put in place in 2001 and advocates demand-driven extension services and participation of other players like community based organizations in the delivery system (Republic of Kenya, 2004). The NAEP has served as the instrument by which the Ministry of Agriculture and Livestock and Fisheries is facilitating extension under the National Agriculture and Livestock Extension Programme (NALEP) and the NALEP Implementation Framework (Republic of Kenya, 2004).

\section{Statement of the Problem}

Kenyas' agricultural extension services are characterized by multiplicity of players. There are myriads of challenges involved with each of the extension service provider (Evenson and Mwabu, 1998). The main extension service providers include; public extension sector under ministry of agriculture, private extension providers under various cash crops programs, Non-governmental organizations (NGOs), Community Based Organizations (CBOs) and farm inputs and agro-chemical companies (Munyua and Stilwell, 2010).

Community based initiatives have been identified as a way to have a bottom up approach to implementing agricultural extension services in communities. This has proven to be of great advantage to the communities in terms of capacity building and fostering self-reliance among communities thus enabling sustainability of projects. Rees et al., (2000) noted that, many self-help groups are well developed, particularly in the higher potential areas of the country, and provide potential entry points for knowledge dissemination and generation.

The success of community based organizations in easing up the information gap in the provision of extension in agriculture is influenced by several factors some of which act as impediments while others expedite the process. This study therefore sought to investigate factors that influence the performance of community based organizations (CBOs) in implementing agricultural extension services in Buuri Sub County, Meru County. Specifically the study looked at the influence of; community participation, funding, governance and operational framework.

\section{RESEARCH HYPOTHESIS}

$\mathbf{H}_{\mathbf{0}}$ : Operational Frameworks do not have a significant relationship with accessibility of building infrastructure by physically challenged persons.

$\mathbf{H}_{1}$ : Operational Frameworks have a significant relationship with accessibility of building infrastructure by physically challenged persons.

\section{Operational Frameworks and Performance of Community Based Organizations IMPLEMENTING AGRICULTURAL EXTENSION SERVICES}

\subsection{Skilled Staff}

Kidd, et al., (2000) in their study of China's privatized agricultural extension program, argue that the program suffered due to the limited access to subject matter specialists. They further argue that most CBOs contracted to provide extension services lacked experienced staff in the specific needs of farmers. Most CBOs' staff had general experience and could therefore not meet the priorities of farmers. Problems of inadequate availability of qualified service providers also afflicted the voucherbased extension programs in Chile and Costa Rica in the early 1990s (Ameur 1994; Bebbington and Sotomayor, 1998). 
In his study in Indonesia, Matteson et al., (1992), pointed out that although CBOs play an important complementary role within national extension strategies, a local CBO's team felt that the limited scope of their projects prevented them from being the main channel for diffusing IPM extensively. Field leaders and pest observers were trained for 15 months in IPM and facilitation skills in regional IPM training centers (van de Fliert et al., 1995). The program's strategy was not to train individual farmers but to establish an IPM capacity in each community and then support its horizontal diffusion (Settle et al., 1998; van de Fliert et al., 1995).

Thomas MJ.(1998) in a study in India and South Asian countries, asserted that many community based rehabilitation programs run by CBOs often did not have monitoring and evaluation systems, nor did they define their outcomes or attempt to measure them. Instead, they repeated a set of activities year after year, with some illustrations and anecdotes from their clients, to justify why they had to continue their activities. Such activities tended to be donor dependent, cost-intensive, seldom successful, rarely sustained once the donor withdrew support.

In many developing countries there is a rather thin market of qualified service providers, and the situation is exacerbated by the vulnerability of the accreditation mechanism to corruption and political manipulation. Kazigati, (2005) and Nyanzi, (2005) in their separate studies of CBOs engaged in the provision of extension services through the NAADS program in Uganda point out inadequacy of service providers and the resultant low quality of service. Further they posit that the skills of CBOs extension staff in many developing countries were built on a slender educational preparation and were geared toward generic technology messages, rather than the more specific and localized issues that farmers tend to identify as their priorities. Similarly, Ekwamu and Brown, (2005) reported that the quality of service provision by these CBOs emerged as a major issue in personal interviews with farmer groups.

\subsection{Adoption of Monitoring and Evaluation and Information Communication Technologies}

Muwonge, (2007) in his study in Uganda not only raised concerns regarding service quality, but also through his field interviews questioned the ability by CBOs' staff to carry out quality impact monitoring and evaluation of their extension services. It was also found that some CBOs were not good at giving feedback on the new technologies introduced to farmers (Sanders and McMillan, 2001). In their study, Edwards and Hulme, (1996) also criticized CBOs for failure to develop methods for monitoring and evaluating their performance, providing accountability and conducting strategic planning. Though Bindlish and Evenson, (1993) in their study in Kenya of the T\&V programme reported a high and significant rate of returns to extension, they did report that most community based organizations providing agricultural extension services had poor monitoring and evaluation systems. Furthermore, innovations are inherently messy, chaotic, complex and unpredictable (Leeuwis, 2004).

Performance of CBOs in Kenya remains wanting due to constraints originating from external environment and lack of expertise in monitoring and analyzing external environment (Odindo, 2009). Lyne and Collins, (2008) in their study report that deficient support systems such as external monitoring and evaluation, and lack of a supportive policy environment among CBOs have also contributed to agricultural extension projects failures. According to Zulu, (2007) monitoring and evaluation programmes; and a lack of appropriate ICT skills were the crucial factors that contributed to failure of extension programs. According to Omolo et al., (2001) some CBOs were not good at giving feedback on the new technologies introduced. Some CBOs are lacking in capacity in terms of staff, facilities and technological expertise. CBOs have also been criticized for failure to develop methods for monitoring and evaluating their performance, providing accountability and conducting strategic planning (Edwards \& Hulme, 1996).

\subsection{Organizational Structure}

One cannot discuss an organization's operational framework without looking into its organizational structure. Molomo and Somolekae, (1999) have argued that a key weakness of CBOs in Africa is their inappropriate organizational structures which impact on the manner they carry out their core business. Mintzberg, et al., (1985) has written more on the significance of organizational structure in making decisions. Organizational structure refers to the shape, division of labour, job ,duties and 
responsibilities, the distribution of power and decision making procedures within the company, which influences the types of strategy used by an organization. It is a formal framework by which jobs/tasks are divided, grouped and coordinated (Wambugu, 2006). According to Karuri, (2006) organizations implement their strategies through their organization structures. He found out that the positioning of the function in the organization structure is equally important as it sets more focus on key functions whose performance is critical to the success of the business strategy and institutionalizes the decision making of the heads of these functions. Wanyama, (2001) observes that most CBOs have inefficient systems in place and do not have qualified personnel.

\section{Theoretical Perspective}

The current study is pivoted on one theory: Core Competencies Theory developed by (Prahalad \& Hamal, 1990). The theory is premised on the idea that core competencies are the source of competitive advantage and equip the firm to launch a variety of new products and services. Further, they contend core competencies result from the integration of multiple technologies and the coordination of divergent production skills (Prahalad \& Hamal, 1990). Sanchez (2001) another proponent of the Core Competencies Theory underpins that it is only organizations that appreciate the dynamic and complex interplay of competences, assets and resources that are able to tap into both their homogenous and heterogeneous resources to meet their goals.

In employing this theory therefore, this study contends that core competencies lead to the provision of excellent services by an organization. Additionally, this research also holds that the successful implementation of operational frameworks is dependent on competent employees and their capabilities, seen from their bundles of skills and collective learning, knowledge and technological know-how. Further, it is these characteristics that are pivotal to community based organizations' use of operational frameworks that integrate monitoring and evaluation systems and information technologies to enhance service delivery in particular meeting the agricultural extension needs of farmers.

\section{RESEARCH METHODOLOGY}

This study was guided by descriptive survey research design to investigate the relationship between operational frameworks and performance of community based organizations implementing agricultural extension services in Buuri Sub County, Meru County. Descriptive survey research design made it possible for the gathering of qualitative as well as quantitative data on the correlation between operational frameworks and performance of community based organizations implementing agricultural extension services in the study locale. The association between study variables and the problem under investigation was also established through survey research design. This was made feasible by the intrinsic features of survey design which grants researchers an opportunity to interrogate on study respondents' understanding, perspectives and values with respect to the problem been investigated. This study made use of a sample size of 319 respondents consisting of registered CBOs' members and CBOs' officials. Stratified sampling was employed to classify CBOs under study in 3 strata based on their main value chains and Simple random sampling technique was used to select final study subjects from the sample. Questionnaires were administered in person to registered CBOs' members while face to face interview conducted for CBOs' officials. The collected primary data was edited, evaluated on grounds of integrity and finally coded. Descriptive statistics was used to analyze quantitative data making use of Statistical Package for Social Sciences (SPSS) version 21.0 and the results presented using frequency and percentages tables to arrive at a valid inference. Content analysis was then employed to analyze qualitative data which entailed the categorization of data into themes, patterns and sub-topics modeled on the objectives under investigation.

\section{FINDINGS AND INTERPRETATION}

The study sought to establish the relationship between operational frameworks and performance of community based organizations (CBOs) implementing agricultural extension services.

\subsection{Reports on the Existence of Monitoring and Evaluation System in CBOs}

Study respondents were requested to indicate whether their respective CBO's had put in place a working monitoring and evaluation system. The findings were as shown in Table 1. 
Relationship Between Operational Frameworks and Performance of Community Based Organizations Implementing Agricultural Extension Services in Buuri Sub-County, Meru County, Kenya.

Table1: Existence of Working Monitoring and Evaluation System in CBOs

\begin{tabular}{|l|l|l|}
\hline Opinion & Frequency & Percentage \\
\hline Yes & 241 & 88.3 \\
\hline No & 32 & 11.7 \\
\hline Total & $\mathbf{2 7 3}$ & $\mathbf{1 0 0 . 0}$ \\
\hline
\end{tabular}

As shown in Table 1, majority of the respondents $88.3 \%$ agreed that the CBO had a monitoring and evaluation system in place whereas $11.7 \%$ was of the contrary opinion. This implies that most of the CBOs had a monitoring and evaluation system in place which influenced their performance in agricultural extension services in terms of; providing a consolidated source of information showcasing project progress, generating (written) reports that contribute to transparency and accountability and allowed for project lessons to be shared more easily.

\subsection{Staff Qualifications in Agricultural CBOs}

Study respondents were also requested to indicate whether current staffs in their respective CBO's were qualified for their roles. The findings were as shown in Table 2.

Table2: Current Staff Working in CBOs Qualified for Their Roles

\begin{tabular}{|l|l|l|}
\hline Opinion & Frequency & Percentage \\
\hline Yes & 210 & 76.9 \\
\hline No & 63 & 23.1 \\
\hline Total & $\mathbf{2 7 3}$ & $\mathbf{1 0 0 . 0}$ \\
\hline
\end{tabular}

From the research findings majority of the respondents agreed as shown by $76.9 \%$ that the current staff working for the organisation was well qualified for their roles whereas $23.1 \%$ of the respondents were of the contrary opinion. This implies that most current staff working for the CBO were well qualified for their roles indicating these organizations recognized impact of workers on their performance in agricultural extension services.

\subsection{Adoption and Use of Information Communication Technologies in Agricultural Extension}

The respondents were requested to indicate whether their respective CBOs had adopted ICT in implementing agricultural extension services. The results were as shown in Table 3.

Table3: Adoption and use of ICTs in agricultural extension services

\begin{tabular}{|l|l|l|}
\hline Opinion & Frequency & Percentage \\
\hline Yes & 255 & 93.4 \\
\hline No & 18 & 6.6 \\
\hline Total & $\mathbf{2 7 3}$ & $\mathbf{1 0 0 . 0}$ \\
\hline
\end{tabular}

From the research findings majority of the respondents as shown by $93.4 \%$ agreed that the CBO has already adopted the use of ICTs in the implementation of agricultural extension services whereas $6.6 \%$ of the respondents were of the contrary opinion. This implies that most CBOs had adopted the use of ICTs and also indicated they appreciated the significant role ICT plays in enhancing efficiency in the implementation of agricultural extension services.

\subsection{Working Organizational Structure}

The respondents were requested to indicate whether their respective CBOs had put in place a working organizational structure. The results were as shown in Table 4.

Table4: Existence of Working Organizational Structure in CBOs

\begin{tabular}{|l|l|l|}
\hline Opinion & Frequency & Percentage \\
\hline Yes & 222 & 81.3 \\
\hline No & 51 & 18.7 \\
\hline Total & $\mathbf{2 7 3}$ & $\mathbf{1 0 0 . 0}$ \\
\hline
\end{tabular}

Based on the research findings, majority of the respondents as shown by $81.3 \%$ agreed that the CBO has a working organizational structure in place whereas $18.7 \%$ of the respondents were of the contrary opinion. This implies that the $\mathrm{CBO}$ recognized the importance of having a working organizational structure in place to enhance their performance in implementing agricultural extension services. 
Relationship Between Operational Frameworks and Performance of Community Based Organizations Implementing Agricultural Extension Services in Buuri Sub-County, Meru County, Kenya.

Research study respondents were also requested to indicate their level of agreement with following statements on their respective CBO's Operational Frameworks. The results were as shown in Table 5.

Table5: Influence of operational frameworks on CBOs in agricultural extension services

\begin{tabular}{|c|c|c|c|c|c|c|c|}
\hline Statement & 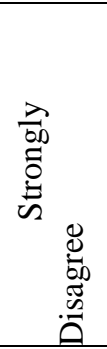 & 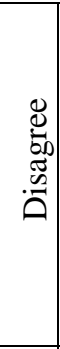 & 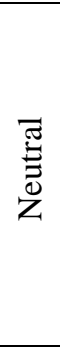 & 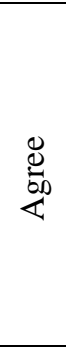 & 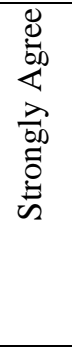 & $\stackrel{\Xi}{\sum_{\Sigma}^{ \pm}}$ & 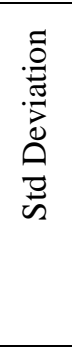 \\
\hline $\begin{array}{l}\text { The use of ICTs in the implementation of agricultural } \\
\text { extensions services projects does not improve projects' results. }\end{array}$ & 217 & $\begin{array}{l}5 \\
0\end{array}$ & 6 & 0 & 0 & $\begin{array}{l}1.2 \\
3\end{array}$ & 0.47 \\
\hline $\begin{array}{l}\text { An effective M\&E system does improve the results of } \\
\text { agricultural extension services implemented by CBOs. }\end{array}$ & 0 & 0 & 13 & 55 & 205 & $\begin{array}{l}4.7 \\
0\end{array}$ & 0.55 \\
\hline $\begin{array}{l}\text { Employment of unqualified CBOs' staff does not affect the } \\
\text { performance of CBOs in the implementation of agricultural } \\
\text { services. }\end{array}$ & 179 & $\begin{array}{l}7 \\
7\end{array}$ & 17 & 0 & 0 & $\begin{array}{l}1.4 \\
1\end{array}$ & 0.61 \\
\hline $\begin{array}{l}\text { A clear working organizational structure enhances performance } \\
\text { of CBOs implementing agricultural extension services projects. }\end{array}$ & 0 & 0 & 16 & 79 & 178 & $\begin{array}{l}4.5 \\
9\end{array}$ & 0.60 \\
\hline Average mean & & & & & & 3.0 & 0.56 \\
\hline
\end{tabular}

From the research findings majority of the respondents strongly agreed that; an effective M\&E system does improve the results of agricultural extension service projects implemented by CBOs as shown by a mean of 4.70 and that a clear working organizational structure by CBOs enhances performance of CBOs implementing agricultural extension services projects as shown by a mean of 4.59. The study also noted that majority of the respondents disagreed that the use of ICTs in the implementation of agricultural extension services projects does not improve projects' results as shown by a mean of 1.23 and that employment of unqualified CBOs' staff does not affect the performance of CBOs in the implementation of agricultural services as shown by a mean of 1.41 .

\subsection{Inferential Statistics and Regression Results}

The data presented before on Community Participation, Funding, Operational Framework, Operational Framework and Performance of CBOs in implementing agricultural extension Service were computed into single variables per factor by obtaining the averages of each factor. Correlations analysis and multiple regression analysis were then conducted at 95\% confidence interval and 5\% confidence level 2-tailed to establish the relationship between the variables. The research used statistical package for social sciences (SPSS V 21.0) to code, enter and compute the measurements of the Pearson's Product Moment Correlation and multiple regression.

\subsection{Pearson's Product Moment Correlation}

A Pearson's Product Moment Correlation was conducted to establish the strength of the relationship between the variables under study. The findings are presented in Table 6.

Table6: Correlations Table

\begin{tabular}{|l|l|l|}
\hline \multirow{2}{*}{$\begin{array}{l}\text { Performance of Community Based Organizations } \\
\text { implementing extension services }\end{array}$} & $\begin{array}{l}\text { Performance of Community Based Organizations } \\
\text { implementing Agricultural Extension services }\end{array}$ \\
\cline { 2 - 3 } & Pearson Correlation & 1 \\
\hline Operational Frameworks & Sig. (2-tailed) & \\
\cline { 2 - 3 } & Pearson Correlation & .881 \\
\cline { 2 - 3 } & Sig. (2-tailed) & .056 \\
\hline
\end{tabular}

Based on result in Table 6, the study established that there was a very strong, positive and significant correlation between Operational Frameworks and Performance of CBOs Implementing Agricultural 
Extensions services at $(\mathrm{r}=0.881, \mathrm{p}$ value $=0.056)$. This result indicates that the variable under investigation had a positive and significant correlation with the performance of CBOs implementing agricultural extension services projects in the study locale.

\subsection{Multivariate Regression Analysis Results}

The current study used a regression model to test the hypothesis between Operational Frameworks and Performance of CBOs in implementing agricultural extension services. Results are as presented in Table 7.

Table7: Summary of the Regression Model Output

\begin{tabular}{|l|l|l|l|l|}
\hline Model & R & R Square & Adjusted R Square & Std. Error of the Estimate \\
\hline 1 & 0.827 & 0.684 & 0.673 & 2.239 \\
\hline Predicator: (constant) & Operational Frameworks & \\
\hline Dependent: Variable. & $\begin{array}{l}\text { Performance of Community Based } \\
\text { implementing Agricultural Extension services }\end{array}$ & \\
\hline
\end{tabular}

The current research study made use of the Adjusted $\mathrm{R}$ squared as the coefficient of determination to provide information on changes in the dependent variable emanating from variations in the independent variable. According to study results on Table:7 the value of adjusted $\mathrm{R}$ squared was 0.741 indicating that there was variation of 74.1 percent on performance of community based organizations implementing agricultural extension services emanating from operational frameworks at 95 percent confidence interval. Based on these findings it was deduced that Operational Frameworks accounted for $67.3 \%$ of the variations in the performance of community based organizations implementing agricultural extension services in the county

The study also applied Regression coefficients to determine correlations between the independent variable (operational frameworks) and performance of community based organizations implementing agricultural extension services. Findings are as shown in Table 8.

Table8: Regression coefficients

\begin{tabular}{|l|l|l|l|l|l|}
\hline \multirow{2}{*}{ Model } & \multicolumn{2}{l|}{$\begin{array}{l}\text { Un standardized } \\
\text { Coefficients }\end{array}$} & Standardized Coefficients & t & Sig. \\
\cline { 2 - 7 } & B & Std. Error & Beta & & \\
\hline (Constant) & 1.053 & 0.217 & & 2.889 & .005 \\
\hline Operational Frameworks & 0.763 & 0.091 & 0.138 & 3.989 & 0.00 \\
\hline
\end{tabular}

Based on the data in Table 8, the established regression equation was

$\mathbf{Y}=1.053+(0.763)$

Based on the regression equation above, it was established that taking operational frameworks into account constant at zero, the performance of community based organizations (CBOs) in the study locale was 1.053 . The study also found that a unit increase in the scores for operational frameworks would lead to a 0.763 increase in the scores of Performance of CBOs in implementing agricultural extension services. The variable under study was at a significance value of 0.000 which is $<0.05$ which meant operational frameworks to an appreciable degree influenced the performance of CBOs implementing agricultural extension services projects in Meru County. From this finding, the Null hypothesis that operational frameworks do not have a significant relationship with the performance of CBOs implementing agricultural extension services projects is rejected and the Alternative hypothesis; operational frameworks have a significant relationship with the performance of CBOs implementing agricultural extension services projects is accepted.

\section{Conclusions}

The study concluded that operational frameworks had a pivotal role in performance of CBOs providing agricultural extension services as they promoted a corporate culture and integrated principles of good governance in the organizations. This is because an operational framework sets out the way the CBOs conducted their operations and also acted as a guide to organizational policies, goals and procedures. 
Relationship Between Operational Frameworks and Performance of Community Based Organizations Implementing Agricultural Extension Services in Buuri Sub-County, Meru County, Kenya.

\section{RESEARCH STUDY RECOMMENDATIONS}

The study recommends that to attain set out goals and excellent performance in the provision of agricultural extension services, CBOs in the study locale must have strong operational frameworks in place. Further, the adopted operational framework should provide a set of knowledge areas (or criteria) used to guide continual improvement within the organization and provide a results-driven methodology used to plan, implement, measure, and continually improve the organization's program.

\section{REFERENCES}

[1] Adejumobi, A. (1997). Prospect and problems of community organization and mobilization for selfreliance. Ibadan: NISER

[2] Ameur, C. (1994). Agricultural extension: a step beyond the next step. Washington, DC: The World Bank.

[3] Anderson, J., and Feder, G. (2004) Agricultural extension: Good intentions and hard realities.

[4] The World Bank Research Observer, 19 (1): pp.41-60.

[5] Anderson, J.R. and Feder, G. (2007). Handbook of Agricultural Economics, vol.3. Chapter 44: Agricultural Extension. Edited by Evenson, R. and Pingali, P. agriculture and Rural Development Department, World Bank, Washington, DC. pp.2344 - 2367. DOI.10.1016/S1574-0072 (06)03044-1.

[6] Awa, E. A, and Ema, A. O. (1992). Political factors in rural development in Nigeria. Proceedings of the 1992 annual conference of the Nigeria Economic Society, Ibadan.

[7] Bebbington, A., and Sotomayor, O. (1998).Demand-led and poverty-oriented... Or just subcontracted and efficient? Learning from (semi-) privatized technology transfer programmers in Chile. Journal of International Development, 10(1), 17-34.

[8] Bindlish, V. and Evenson, R. (1993). Evaluation of the Performance of the T\&V Extension in Kenya. World Bank Technical Paper 208. Washington D.C

[9] Birkhaeuser, D., Evenson, R.E., and Feder, G. (1991). The economic impact of agricultural extension: a review. Economic Development and Cultural Change 39 (3) pp.607-640.

[10] Dillman, D. A., (1986). Co-operative extension at the beginning of the $21^{\text {st }}$ century. The Rural Sociologist 6(2), pp.102-119.

[11] Edwards, M., and Hulme, D., (Eds.) (1996). Beyond the magic bullet: NGO performance and accountability in the post-cold war world. West Hartford, Connecticut: Kumarian Press.

[12] Ekpere, J.A. (1991). Agricultural Extension, Searchlight of the Nigerian Small Farmers. 1990 University Lectures. Ibadan: University of Ibadan Press 3p.

[13] Ekwamu, A., and Brown, M. (2005). Four years of NAADS implementation: Programme outcomes and impact. In Proceedings of the mid-term review of the National Agricultural Advisory Services, 25-39. Kampala, Uganda: Ministry of Agriculture, Animal Industry, and Fisheries.

[14] Evenson, R. and Mwabu, G. (1998): The effects of Agricultural Extension on Farm Yields in Kenya. Economic Growth Center Discussion Paper No. 798. Yale University. New Haven.

[15] Fakoya, G, O, Apantaku, S.O, and Oyesola, O, B. (2000). Contribution of local associations in community development projects in Ondo State, Nigeria. J. Agric. Soc. Res., 1 (2),

[16] FAO. (2003).Nepal: A study on issues and problems arising from decentralization of agricultural extension services, unpublished report of a study conducted by M.K.Qamar and K.N. Pyakuryal. Rome.

[17] Farrington, J., Christoplos, I., Kidd, A., and Beckman, M. with Cromwell E. (2002), "Creating a policy environment for pro-poor agricultural extension: The Who? What? And How?" Natural Resource Perspectives 80, ODI, London.

[18] Garforth, C. (2002). ADAS and the privatization of advisory services in England and Wales. Case study prepared for International Workshop on Extension and Rural Development. Washington, DC.

[19] Hercus, J. (1991). The commercialization of government agricultural extension services in New Zealand. Agricultural Extension: worldwide institutional Evolution \& Forces for change. Rivera, W.M. and Gustatson, D.J. (Eds). New York, Elsevier.

[20] Karuri, T.W. (2006).Challenges of strategy implementation in development of financial institutions. Unpublished MBA Research Project. University of Nairobi. Nairobi

[21] Kazigati, G. (2005). Performance of NAADS districts: Kabarole. In Proceedings of the mid-term review of National Agricultural Advisory Services, 44-46. Kampala, Uganda: Ministry of Agriculture, Animal Industry, and Fisheries. 
Relationship Between Operational Frameworks and Performance of Community Based Organizations Implementing Agricultural Extension Services in Buuri Sub-County, Meru County, Kenya.

[22] Kibett, J.K, Omunyin and Muchiri, J. (2012).Elements of agricultural extension policy in Kenya: Challenges and opportunities African Crop Science Conference Proceedings, Vol.7. pp. 1491-1494

[23] Kidd, A., Lamers, J., Ficarelli, P. and Hoffmann, V. (2000), 'Privatising Agricultural Extension:

[24] Caveat Emptor', Journal of Rural Studies, vol.16, pp.95-102.

[25] Le Gouis, M. (1991). Alternative financing of agricultural extension: Recent trends and implications for the future. In W. M. Rivera\& D. J. Gustafson (Eds.), Agricultural extension: Worldwide institutional evolution and forces for change. Amsterdam: Elsevier.

[26] Leeuwis, C. (with contributions by A. Van den Ban) (2004). Communication for rural innovation. Rethinking agricultural extension. Blackwell Science / CTA, Oxford / Wageningen.412p.

[27] Lyne, M., and Collins, R. (2008). South Africa's new Cooperatives Act: A missed opportunity for small farmers and land reform beneficiaries. Agrekon, 47(2), 180-197.

[28] Matteson, P.C., Gallagher, K.D. and Kenmore, P.E. (1992) 'Extension of integrated pest management for plant hoppers in Asian irrigated rice: empowering the user' in R.F. Denno, and T.J. Perfect (Eds) Ecology and Management of Planthoppers. London: Chapman and Hall.

[29] Molomo, M. and Somolekae, G. (1999), Making a Difference: NGOs, Good Governance and Service Delivery. In Public Administration and Policy in Botswana, Juta \& Co. Ltd, Kenwyn Cape Town

[30] Mubangizi, N., M.N. Mangheni and C.J. Garforth. (2014). Information sources and constraints under national agricultural advisory services program of service providers in Uganda. Uganda Journal of Agricultural Sciences 9: 257-264. Extension services in sub-Saharan Africa. The Journal of Agricultural Education and Extension, Vol. 8, No. 1; 1-11.

[31] Munyua, H., and Stilwell, C., (2010). A mixed qualitative-quantitative-participatory methodology: A study of the agricultural knowledge and information system (AKIS) of small-scale farmers in Kirinyaga district, Kenya. Library management, 31(1/2), 5-18.

[32] Muwonge, A. (2007). Local government financing and provision in an institutionally constrained decentralized system: The case of agricultural extension in Uganda. Ph.D. dissertation, Andrew Young School of Policy Studies, Georgia State University, Athens, Georgia, U.S.A.

[33] Nambiro, E., Omiti, J., and Mugunieri, L. (2006, August). Decentralization and access to agricultural extension services in Kenya. In International Association of Agricultural Economists, 2006 Annual Meeting (pp. 12-18).

[34] Nyanzi, A. (2005), "Performance of NAADS districts: Mukono", in Proceedings of the Mid-Term Review of National Agricultural Advisory Services, Ministry of Agriculture, Animal Industry, and Fisheries, Kampala, p.46, available at: http://naads.or.ug/manage/reports/44docMTR.pdf (accessed 18 May 2016).

[35] Odindo, M. (2009). Capacity Needs of CBOs in Kenya to Apply for Global Fund Grants; an AfricanEuropean Initiative. Cologne: Stop Malaria Now.

[36] Okwu, O.J, and Ejembi, E.P (2001). The Historical Development of Agricultural Extension in Nigeria. J. Sust. Trop Agric. Res. 2(3): 93 -99.

[37] Omolo, E. O., Sanders, J. H., McMillan, D. E., and Georgis, K. (2001). Agricultural technology for the semiarid Africanhorn. Country study: Kenya. BIGAD /INTSORMIL/USAID-RESDO. Lincoln, Nebraska: INTSORMIL.

[38] Oryokot, J. (2003). Increasing Farmer Access to Information, Knowledge and Technologies. The role of ICTs. ICTs - Transforming Agricultural Extension?

[39] Prahalad, C.K. and Hamel, G. (1990). 'The core competence of the corporation' Harvard Business Review 68(3):79-91.

[40] Purcell, D., and Anderson, J. R. (1997). Agricultural extension and research: Achievements and problems in national systems. World Bank Publications.

[41] Republic of Kenya, (2004). National Agriculture and Extension Program; NALEP. Draft Project Proposal, Phase II. July, 2004 - June 2009. Ministry of Agriculture; and Ministry of Livestock and Fisheries Development. 76p

[42] Rees, D., M. Momanyi, J. Wekundah, F. Ndungu, J. Odondi, A. O. Oyure, D. Andima, M. Kamau, J. Ndubi, F. Musembi, L. Mwaura and R. Joldersma. (2000). Agricultural knowledge and information in Kenya - implications for technology dissemination and development. ODI Agricultural Research \& Extension Network Paper No.107 Rivera, W.M. 2013. The Invisible Frontier: the Current Limits of Decentralization and Privatization in the Developing Countries.

[43] Rivera, W.M. (2013). The Invisible Frontier: the Current Limits of Decentralization and Privatization $n$ the Developing Countries. InF. Brewer (ed.), Agricultural Extension: An International Perspective (2001); Erudition Press. 
Relationship Between Operational Frameworks and Performance of Community Based Organizations Implementing Agricultural Extension Services in Buuri Sub-County, Meru County, Kenya.

[44] Sanchez, R. (2001). Building Blocks for Strategy Theory: Resources, Dynamic Capabilities and

[45] Competences. London: Sage.

[46] Sanders, J., and McMillan, D.E. (Eds.) (2001). Agricultural technology for the semiarid Africanhorn. Vol.1: Regional synthesis. IGAD/INTSORMIL/USAID-RESDO. Lincoln, Nebraska: INTSORMIL.

[47] Settle, W.H., Whitten, M., Dilts, R. and Ooi, P.A.C. (1998) 'Developments in community IPM for irrigated rice in Asia'. Paper presented at the Sixth Australasian Applied Entomological Research Conference, 29 September to the 6 October 1988, Brisbane, Australia.

[48] Shekara, C., and Charyulu, A. (2002) "Agriculture to agripreneurship: Success stories of agripreneurs. Hyderabad: National Institute of Agriculture Extension Management (MANAGE)”.pp-34-36.

[49] Van de Fliert, Elske, J. Pontius and Roling. N. (1995). "Searching for Strategies to Replicate a Successful Extension Approach: Training of IPM Trainees in Indonesia." Journal of Agricultural Education and Extension 1:41-63.

[50] Wambugu, C. (2006). Factors influencing the effectiveness of farmers as disseminators of fodder shrubs in the central Kenya highlands. Retrieved from: http://www.icraf.org/ downloads/ publications/PDFs/ pp06106.doc

[51] Wanyama, Fredrick O. (2001), "Grassroots Organization for Sustainable Development: The Case of Community-Based Organizations in Western Kenya," Regional Development Studies, Vol. 7.

[52] Wilson, M. (1991). Reducing the cost of public extension: Worldwide Institutional Evolution \& Forces for Change. Rivera, W. M. and Gustatson, D.J. (eds) New York, Elsevier

[53] World Bank/USAID. (2002). Extension and Rural Development: a Convergence of Views on Institutional Approaches? International Workshop, Nov. 12-14. The World Bank. Washington, D.C.

[54] Zulu, G., (2007). Agricultural Community Service Organizations I: history, theory and problems. Agrekon 46:40-68.

Citation: N. M. Hezekiel Waweru, W. John, "Relationship between Operational Frameworks and Performance of Community Based Organizations Implementing Agricultural Extension Services in Buuri SubCounty, Meru County, Kenya, vol. 3, no. 11, p. 35-45, 2017. http://dx.doi.org/10.20431/2454-6224.0311003

Copyright: () 2017 Authors. This is an open-access article distributed under the terms of the Creative Commons Attribution License, which permits unrestricted use, distribution, and reproduction in any medium, provided the original author and source are credited. 